Wanastra : Jurnal Bahasa dan Sastra

Volume 13 No. 2 September 2021

P-ISSN 2086-6151 E-ISSN 2579-3438

https://doi.org/10.31294/w.v12i1

\title{
Morfologis Analisis Dalam Puisi Embun Di Hutan Jati Karya Candra Malik
}

\begin{tabular}{ccc} 
Sri Mulyati \\
Universitas Bina Sarana Informatika \\
sri.smq@ bsi.ac.id \\
\hline
\end{tabular}

\begin{abstract}
The writer analyzed a poem by Candra Malik entitled "Embun Di Hutan Jati". This is an old type of poem which has four stanzas, twenty-four lines of sentences, and is in a closed form. The object of this research focuses on the bound morpheme, morph, and allomorph contained in each line in the poem. The purpose of this study was to show the results of the analysis limited to bound morpheme, morph, and allomorph. Morpheme is the smallest grammatical unit that cannot be further divided and has meaning, morph is the smallest grammatical unit whose status is not yet known in the membership of a morpheme and has no meaning, while allomorph is part of the morpheme that has a clear position and contribution and has meaning. Another purpose is to develop the potential of language as a teaching medium and it is hoped that it will be able to develop language studies, especially morphemes and affixations. All forms of prefixes and suffixes and the combination of prefixes and suffiesx are called bound morphemes. For further analysis, the writer used a descriptive qualitative approach as a research methodology to reveal the data in each line of the poem. The results shows that "Embun Di Hutan Jati" poem was dominated by bound morphemes in the form of allomorph, namely: meand ber-, also bound base morphem (word that need alomorph or morph).
\end{abstract}

Key words : morphology, morphem, poem

\begin{abstract}
Abstrak - Penulis menganalisa sebuah puisi karya Candra Malik yang berjudul "Embun Di Hutan Jati". Ini adalah jenis puisi lama yang memiliki empat bait, dua puluh empat baris kalimat, dan dengan bentuk tertutup (close form). Objek penelitian ini fokus pada morfem terikat, morf, dan alomorf yang terkandung di dalam setiap baris di dalam puisi tersebut. Tujuan penelitian ini adalah untuk menunjukkan hasil analisa yang dibatasi pada morfem terikat, morf, dan alomorf. Morfem adalah satuan gramatikal terkecil yang tidak dapat dibagi lagi dan memiliki makna, morf adalah satuan gramatikal terkecil yang belum diketahui statusnya dalam keanggotaan terhadap sebuah morfem, dan dan tidak memiliki makna, sementara alomorf adalah bagian dari morfem, yang sudah jelas kedudukannya dan kontribusinya serta meiliki makna. Tujuan lainnya adalah mengembangkan potensi bahasa sebagai media pengajaran dan diharapkan mampu mengembangkan kajian bahasa khususnya morfem dan afiksasi. Semua bentuk awalan dan akhiran serta gabungan awalan dan akhiran disebut morfem terikat. Untuk analisa lebih lanjut, penulis menggunakan pendekatan kualitatif deskriptif sebagai metode penelitian untuk mengungkap data dalam tiap baris puisi. Hasil penelitian menunjukkan bahwa puisi "Embun Di Hutan Jati" lebih didominasi morfem terikat yang berupa alomorf, yaitu: me- dan -ber, juga morfem dasar terikat (kata yang membutuhkan morfem alomorf atau morf).
\end{abstract}

Kata kunci : morfologi, morfem, puisi

\section{PENDAHULUAN}

Linguistik adalah ilmu yang mempelajari tentang bahasa, dan penggunaannya sebagai alat komunikasi. Linguistik juga mempelajari struktur bahasa dan segala aspek yang ada di dalamnya. Dalam linguistik terdapat beberapa cabang kajian ilmu di antaranya adalah: fonologi, morfologi, semantik, pragmatik, dan sintax. Morfologi adalah salah satu cabang ilmu linguistik yang memepelajari tentang seluk-beluk struktur internal kata dan pengaruh perubahan struktur tersebut terhadap arti dan golongan kata. Struktur internal kata terdiri dari satuan-satuan gramatik terkecil yang disebut morfem.
Oleh karena itu, objek kajian yang terbesar dalam morfologi adalah kata dan yang terkecil adalah morfem. Kemudian di dalam morfem ada alomorf dan morf. Pengertian lain, morfologi adalah cabang ilmu linguistik yang mengidentifikasi seluk - beluk pembentukan kata serta dampak dari perubahan bentuk kata terhadap arti (makna) dan kelas kata.

Secara etimologi, kata morfologi berasal dari kata 'morf' yang berarti 'bentuk' dan kata 'logi' yang berarti 'ilmu'. Jadi secara harfiah kata morfologi adalah ilmu tentang bentuk. Dari definisi-definisi di atas diperkuat dengan beberapa pendapat dari beberapa tokoh di bidang bahasa, di antaranya 
adalah; Menurut pendapat Chaer, "morfologi adalah ilmu kebahasaan . morfologi adalah ilmu mengenai bentuk-bentuk dan pembentukan kata". (Chaer,3:2008). Berdasarkan pendapat ini dapat disimpulkan bahwa morfologi adalah salah satu cabang ilmu linguistik yang focus pada bentuk dan pembentukan kata.

Pendapat lain dari Ramlan, "Morfologi adalah bagian ilmu Bahasa yang mempelajari seluk -beluk kata serta pengaruh perubahan-perubahan bentuk kata terhadap golongan dan arti kata".29:2009). Berdasarkan pendapat di atas dapat disimpulkan bahwa morfologi adalah salah satu bagian ilmu linguistik yang focus pada mempelajari seputar pengaruh perubahan bentuk kata dan arti kata.

Berikutnya pendapat menurut Tarigan, "Morfologi ialah bagian dari ilmu bahasa yang membicarakan seluk-beluk bentuk kata serta pengaruh perubahan-perubahan bentuk kata terhadap golongan dan arti kata.(Tarigan, 4:1987) dalam Dhanawaty,dkk, 47:2017). Berdasarkan pendapat tersebut dapat disimpulkan bahwa mprfologi adalah salah satu bagian dari linguistik yang mempelajari tentang seluk-beluk kata serta pengaruh terhadap perubahan bentuk kata.

Menurut Ogrady, "Morfologi adalah kategori sistem dan aturan yang melibatkan pembentukan kata dan interpretasinya". OGrady, 113:1997). Berdasarkan pendapat ini dapat disimpulkan bahwa morfologi adalah salah satu bagian linguisti yang fokus pada bentuk dan pembentukan kata serta maknanya. Menurut Verhaar, "Morfologi adalah bidang linguistik yang mempelajari susunan bagianbagian kata secara gramatikal". (Verhaar, 52:1984). Jadi berdasarkan pendapat ini morfologi adalah ilmu yang mempelajari struktur kata yaitu morfem dan pembentukannya.

Manusia adalah satu-satunya makhluk Tuhan yang memiliki bahasa. Hal ini mengantarkan manusia pada studi tentang bahasa serta strukturnya. Morfologi mengatur unit-unit terkecil yang memiliki makna dalam sebuah bahasa. Manusia hidup bergantung pada salah satunya terbentuknya jalinan komunikasi antar sesama. Komunikasi terjadi karena adanya suara yang menghasilkan susunan kata-kata, frase, dan akhirnya membentuk kalimat. Dari situlah pesan dan maksud dikirim dari manusia yang satu ke yang lainnya. Untuk meningkatkan pemahaman mengenai morfologi, kita perlu mengetahui terlebih dahulu istilah morfem. Morfem adalah unit terkecil dari sebuah kata dan memiliki makna. Jadi morfem lebih dari sekedar huruf. Dengan kata lain, morfem adalah sekelompok huruf yang digabungkan hingga membentuk kata dan memiliki makna.

Definisi lain mengenai morfem adalah membedakan arti. Berasal dari kata 'morphe' yang berarti bentuk kata dan 'ema' yang berarti membedakan arti. Morfem tidak dapat dibagi menjadi bentuk yang lebih kecil dari sebuah Bahasa lagi. Dalam tata Bahasa inggris morfem berfungsi sebagai pembeda bentuk benda jamak, menjelaskan menjelaskan masa lalu (past time), dan menjelaskan waktu yang sedang berlangsung,

Menurut Chaer, "Morfem adalah satuan gramatikal terkecil yang mempunyai makna" (Chaer, 1994). Berdasarkan pendapat ini dapat disimpulkan bahwa morfem adalah bagian terkecil dari sebuah bahasa yang memiliki arti. Pendapat lainnya dari kridalaksana, "Morfem adalah satuan bahasa terkecil yang maknanya secara relatve stabil dan yang tidak dapat dibagi atas bagian bermakna yang lebih kecil; misalnya (ter-), (di-), pensil, dan sebagianya adalah morfem. (Kridalaksana, 1993:141). Berdasarkan pendapat tersebut di atas dapat disimpulkan bahwa morfem adalah unsur terkecil dari bahasa yang memiliki arti dan tidak dapat dibagi menjadi unsur yang lebih kecil lagi.

Berikutnya pendapat menurut Keraf, "Morfem adalah kesatuan yang ikut serta dalam pembentukan kata dan yang dapat dibedakan artinya”. (Keraf, 1984). Berdasarkan pendapat ini dapat disimpulkan bahwa morfem adalah unsur terkecil dari bahasa yang dapat membentuk kata dan memiliki arti yang jelas. Sementara morf adalah satuan gramatikal terkecil yang belum diketahui statusnya dalam keanggotaan terhadap suatu morfemdan tidak memiliki makna. Morf adalah morfem yang terikat yang lebih spesifik jenisnya. Dengan kata lain, morf adalah wujud konkret suatu morfem. Pengertian tersebut lebih merujuk pada ciri bentuk atau struktur fonemis suatu morfem tanpa memandang apakah morf itu memiliki arti yang sama atau berbeda dengan morf-morf yang lain. Morf ini berupa imbuhan yang menyatu dengan morfem bebas. Menurut pendapat Odien R, "Morf adalah anggota dari suatu morfem yang belum ditentukan distribusinya atau wujud konkret atau wujud fonemis dari suatu morfem. (Odien.R ,147:2004).

Menurut Kentjono, "Morf adalah bagian dari suatu morfem yang belum menjadi anggota dari morfem tersebut". (Kentjono, 2005). Berdasarkan pendapat ini dapat disimpulkan bahwa morf adalah anggota dari morfem yang belum jelas kedudukannya dan belum memiliki makna. Sedangkan Alomorf adalah bagian dari morfem, yang sudah jelas kedudukannya dan meiliki makna. Menurut Odien, alomorf adalah bagian dari morfem yang telah ditentukan posisi atau distribusinya. Berdasar pendapt ini dapat disimpulkan bahwa alomorf adalah bagian dari morfem yang sudah jelas distribusinya. (Odien, 147;2004).

Menurut Junaiyah, “Alomorf adalah anggota dari suatu morfem yang wujudnya beda tetapi memiliki fungsi dan makna yang sama”. 
(Junaiyah,2007). Berdasarkan. Pendapat ini dapat disimplukan bahwa alomorf adalah bagian dari morfem yang sudah memiliki fungsi dan makna.

Berikutnya adalah puisi. Biasanya karya sastra digunakan untuk menyebut karya imajinasi kreatif. Dengan karya sastra, manusia dapat menggambarkan dan mengeksplorasi imajinasi, emosi, pengalaman, dan idenya melalui karya fiksi maupun non fiksi. Seperti puisi, puisi, lirik lagu, film, dan atau drama. Puisi merupakan seni berbentuk tulisan yang mengandung bahasa dengan kualitas estetika dan memiliki makna yang dalam. Puisi bisa menjadi curahan hati seseorang dan ditulis dengan kata-kata indah yang bermakna. Puisi dapat berisi satu kata atau suku kata yang diulang terus menerus. Puisi merupakan bentuk seni tulis yang mengandung bahasa dengan kualitas estetika dan memiliki makna yang dalam. Puisi bisa menjadi curahan hati seseorang dan ditulis dengan kata-kata indah yang bermakna. Puisi dapat berisi satu kata atau suku kata yang diulang terus menerus.

Knickerboker \& Reninger, (1963; 307) mengatakan bahwa "puisi adalah himne pujian". Pembicaraan yang baik tentang puisi tetap jarang dan bahkan yang terbaik dari itu akan bertumpu pada tanah kosong sampai kita sendiri telah belajar bagaimana menembus kehidupan batin dari beberapa puisi ". Berdasarkan pendapat di atas dapat disimpulkan bahwa Puisi adalah Puisi merupakan media tidak hanya untuk mengungkapkan perasaan penyair tetapi juga untuk membuat kita masuk ke dalam perasaan tersebut tentang hal, orang, situasi atau gagasan dalam puisi. Menurut Reed (1946: 92) dalam Barnet, Berman, dan Burto (1961); "Puisi adalah upaya menuangkan perasaan dan pikiran dalam kata-kata. Puisi juga mencoba melakukan ini dengan cara membuat kesan yang tak terlupakan; ia menggunakan memori, perangkat, dan ide, seperti kiasan, sajak, dan ritme. Puisi dipilih karena pentingnya dokumenter untuk pemahaman penuh tentang periode dan karya penyair jurusan karena keunggulan intrinsiknya. Artinya puisi menggambarkan perasaan, reaksi, dan sikap penulis tentang kehidupan sehari-hari manusia atau puisi juga bisa berbicara tentang fakta kehidupan sosial yang dapat menimbulkan kesan yang berkesan ".

\section{METODE PENELITIAN}

\section{Pendekatan Studi}

Dalam analisis ini, penulis menggunakan metode kualitatif sebagai metodologi penelitian. Metode qualitatif digunakan karena menggambarkan dan menyediakan asumsi dan prosedur yang digunakan secara detail. Metode qualitatif merupakan metode yang tidak menggunakan data statistik. Ini terkait dengan menghasilkan hipotesis dan mengembangkan pemahaman. Pendekatan ini akan membuat penelitian ini mendapatkan informasi yang lebih dalam dan memudahkan pengumpulan datanya.

"Metode kualitatif (atau pendekatan) ilmu manusia dan sosial menawarkan beberapa tradisi. Tradisi ini dapat berupa jenis metode untuk analisis pengumpulan data, dan penulisan pelaporan, atau desain keseluruhan yang mencakup semua tahapan dalam proses penelitian ". (Creswell, 1944). Berdasarkan pendapat di atas dapat disimpulkan bahwa metode kulaitatif adalah metode yang yang menggunakan analisis di tiap tahapan proses supaya hasil penelitian sesuai dengan fakta di lapangan.

\section{Analisis Data}

Dalam menganalisis data, penulis menggunakan metode deskriptif. Metode ini bertujuan untuk memberikan gambaran tentang kondisi suatu situasi secara sistematis, akurat, dan faktual. Sehingga akan lebih mudah untuk memahami arti dari tema tersebut. Metode deskriptif adalah suatu metode yang ringkas untuk mendapatkan dan menganalisis data lebih mudah yang berhubungan dengan materi yang dipelajari. Dengan menggunakan metode deskriptif, penulis mencoba mencari gambaran yang tepat dan cukup melalui proses dan objek. Pada anailsis ini penulis fokus pada kajian morfem terikat, morf dan alomorf dalam sebuah puisi karya Candra Malik yang berjudul "Embun Di Hutan Jati". Ini merupakan puisi lama yang memiliki empat bait, dua puluh empat baris dan menggunakan format tertutup. Melalui metode deskriptif penulis berharap pembaca mendapatkan gambaran yang sebenarnya tentang morfem terikat, morf, dan alomorf dalam tiap baris kalimat puisi tersebut. Jelaslah bahwa menganalisis morfem, morf, alomorf, merupakan salah satu cara untuk memahami makna kata. Ini juga membantu memahami apa yang ingin ditunjukkan penulis kepada pembaca melalui tulisannya di dalam sebuah pusisi karya Chandra Malik.

\section{HASIL DAN PEMBAHASAN}

\section{Morfem Terikat}

Sebenarnya morfem terdiri dari beberapa klasifikasi, dua di antaranya adalah morfem bebas dan morfem terikat. Kedua morfem ini adalah morfem berdasarkan segi kontribusinya. Menurut seorang ahli bahasa, yaitu Keraf, berpendapat "Morfem dapat berupa imbuhan atau kata. Misalnya ber-, di-, juang". (Keraf, 51;1987). Keraf membedakan morfem menjadi dua, yaitu:

a. Morfem bebas, yaitu morfem yang langsung 
dapat membentuk sebuah kaliamat atau morfem yang dapat berdiri sendiri.

b. Morfem terikat, yaitu morfem yang tidak dapat langsung memuat sebuah kalimat, tetapi selalu terikat dengan morfem lain

Namun pada penelitian kali ini penulis hanya fokus pada morfem terikat, morf, dan alomorf. Morfem terikat adalah morfem yang tidak dapat berdiri sendiri dan tidak mempunyai arti. Morfem ini memiliki arti jika sudah digabungkan dengan morfem yang lain, yitu berupa morfem bebas. Semua awalan, imbuhan, dan gabungan antara awalan dan imbuhan adalah juga termasuk contoh morfem terikat, serta kata yang membutuhkan morfem lain juga disebut morfem terikat. Misalnya kata; kerontang dalam kering kerontang, mayur dalam sayur mayur, juang dalam pejuang atau berjuang, temu dalam bertemu atau ketemu, nunggu dalam menunggu, dan sebagainya. Di dalam pemahaman morfem terdapat 'morf' dan 'alomorf'.

\section{Morf}

Morf adalah satuan gramatikal terkecil yang belum diketahui statusnya dalam keanggotaan terhadap suatu morfem dan tidak memiliki makna. Morf adalah morfem yang terikat yang lebih spesifik jenisnya. Dengan kata lain, morf adalah wujud konkret suatu morfem. Pengertian tersebut lebih merujuk pada ciri bentuk atau struktur fonemis suatu morfem tanpa memandang apakah morf itu memiliki arti yang sama atau berbeda dengan morf-morf yang lain. Morf ini berupa imbuhan yang menyatu dengan morfem bebas. Menurut pendapat Odien.R. Morf adalah anggota dari suatu morfem yang belum ditentukan distribusinya atau wujud konkret atau wujud fonemis dari suatu morfem. (Odien.R ,147:2004).

Menurut Kentjono, "Morf adalah bagian dari suatu morfem yang belum menjadi anggota dari morfem tersebut". (Kentjono, 2005). Berdasarkan pendapat ini dapat disimpulkan bahwa morf adalah anggota dari morfem yang belum jelas kedudukannya dan belum memiliki makna. Menurut Kridalaksana, morf adalah anggota morfem yang belum ditentukan (posisi) distribusinya".(Kridalaksana, 2008). Berdasarkan pendapat ini dapat disimpulkan bahwa morf adalah bagian dari morfem yang belum memiliki kedudukan dan belum memiliki makna.

Contoh morfem yang termasuk morf adalah:

a. Anggota morfem yang belum diketahui distribusinya; -I dalam 'mendahului', 'menduduki', dan sebagainya.

b. Ujud konkrit atau ujud fonemis dari morfem; mem- adalah ujud konkrit dari meN- yang

bersifat abstrak . mem- adalah 'morf', meNadalah 'morfem'.

\section{Alomorf}

Alomorf adalah bagian dari morfem yang sudah jelas kedudukannya dan meiliki makna. Menurut Odien, alomorf adalah bagian dari morfem yang telah ditentukan posisi atau distribusinya. Berdasar pendapt ini dapat disimpulkan bahwa alomorf adalah bagian dari morfem yang sudah jelas distribusinya. (Odien, 147;2004). Menurut Junaiyah, "Alomorf adalah anggota dari suatu morfem yang wujudnya beda tetapi memiliki fungsi dan makna yang sama". (Junaiyah,2007). Berdasarkan. Pendapat ini dapat disimplukan bahwa alomorf adalah bagian dari morfem yang sudah memiliki fungsi dan makna.

Contoh morfem adalah: di- memiliki satu alomorf yaitu: di-, morfem se- memiliki satu alomorf yaitu se-, morfem be- memiliki tiga alomorf yaitu: berdalam 'bertemu', be- dalam 'bekerja', bel- dalam 'belajar'. Morfem me- memiliki enam alomorf, yaitu: me- dalam 'melarang', mem- dalam 'membawa', mendalam 'mencuci', 'menyukai, morfem meng- dalam 'mengganggu', mengadu', dan morfem menge- dalam 'mengetahui', 'mengeluh'.

\section{Penyajian Deskripsi Data puisi "Embun di Hutan Jati"}

\section{Puisi Embun Di Hutan Jati “Embun Di Hutan Jati”}

Hutan jati menunggu janji,

Sepanjang hari yang sepi,

Ketika ulat-ulat melingkari.

Jari-jemarinya yang tinggi,

Memekarkan matahari.

Pekarangan luas semesta.

Adalah telapak tangannya.

Menegadah angkasa raya.

Minta embun dan air mata.

Membasahi kelopak bunga.

Terlalu lama dalam gelap,

Sepi beramai - ramai menetap,

Angin mengepung senyap,

Dan terik menolak senyap,

Tunas-tunas bersedekap

Lidah ular tedung menjulur, sakat pandan telah berumur, bertandan-tandan intan sanur, merah dan kuning membaur, mengalungi hutan leluhur.

Kutulis di tanah kemarau, Guguran daun berderau -derau,

Patahan reranting masa lalu: 
Di sini, kau akan kutunggu

Sampai ujung waktuku.

6. Penyajian deskripsi morfem terikat, morf, dan alomorf dalam bentuk table seperti berikut.

Table 1. Morfem terikat Puisi "Embun Di hutan Jati”

\begin{tabular}{|l|c|}
\hline \multicolumn{2}{|c|}{ Morfem Terikat Puisi Embeun Di Hutan Jati } \\
\hline & $\begin{array}{c}\text { Morfem } \\
\text { dasar terikat }\end{array}$ \\
\hline Hutan jati menunggu janji, & nunggu \\
\hline Sepanjang hari yang sepi, & panjang \\
\hline Ketika ulat - ulat melingkari. & lingkar \\
\hline Jari - jemarinya yang tinggi & jemari \\
\hline Memekarkan matahari. & mekar \\
\hline Pekarangan luas semesta. & karang \\
\hline Adalah telapak tangannya. & - \\
\hline Menengadah angkasa raya. & nengadah \\
\hline Minta embun dan air mata & - \\
\hline Membasahi kelopak bunga. & basah \\
\hline Sepi beramai - ramai menetap, & Ramai,netap \\
\hline Angin mengepung senyap, & ngepung \\
\hline Dan terik menolak senyap, & nolak \\
\hline Tunas -tunas bersedekap & sedekap \\
\hline Lidah ular tedung menjulur, & julur \\
\hline sakat pandan telah berumur & umur \\
\hline bertandan - tandan intan sanur, & tandan \\
\hline merah dan kuning membaur, & baur \\
\hline mengalungi hutan leluhur. & Kalung,luhur \\
\hline Kutulis di tanah kemarau, & Tulis, marau \\
\hline $\begin{array}{l}\text { Guguran daun berderau } \\
\text { derau, }\end{array}$ & Gugur, derau \\
\hline Patahan reranting masa lalu: & ranting \\
\hline Di sini, kau akan kutunggu & tunggu \\
\hline Sampai ujung waktuku. & waktu \\
\hline
\end{tabular}

Table 2. Morfem terikat yang termasuk Morf dan Alomorf

\begin{tabular}{|l|l|l|}
\hline Morf dan Alomorf Puisi Embun Di Hutan Jati \\
\hline Baris jati menunggu & Morf & Alomorf \\
\hline $\begin{array}{l}\text { Hutan ja- } \\
\text { janji, }\end{array}$ & & Me- \\
\hline Sepanjang hari yang sepi & & Se- \\
\hline Ketika ulat-ulat melingkari, & -i & Me- \\
\hline Jari-jemarinya yang tinggi & & Nya- \\
\hline Memekarkan matahari, & & Me-, kan- \\
\hline Pekarangan luas semesta & & Pe-, -an \\
\hline Adalah telapak tangannya & & -nya \\
\hline Membasahi kelopak bunga & & Me-, be- \\
\hline $\begin{array}{l}\text { Sepi beramai-ramai } \\
\text { menetap }\end{array}$ & & Me- \\
\hline Angin mengepung senyap & & Me- \\
\hline $\begin{array}{l}\text { Dan terik menolak } \\
\text { senyap }\end{array}$ & Ber- \\
\hline
\end{tabular}

\begin{tabular}{|l|l|l|}
\hline Tunas-tunas bersedekap & & Men- \\
\hline $\begin{array}{l}\text { Lidah ular tedung } \\
\text { menjulur, }\end{array}$ & & Ber- \\
\hline $\begin{array}{l}\text { Sakat pandan telah } \\
\text { berumur }\end{array}$ & Ber- \\
\hline $\begin{array}{l}\text { Bertandan-tandan intan } \\
\text { sanur }\end{array}$ & Mem- & \\
\hline $\begin{array}{l}\text { Merah dan kuning } \\
\text { membaur, }\end{array}$ & Le-, me- \\
\hline Mengalungi hutan leluhur & -i & Ku- \\
\hline Kutulis di tanah kemarau & & -an, ber- \\
\hline $\begin{array}{l}\text { Guguran daun berderau- } \\
\text { derau }\end{array}$ & & Re- \\
\hline Patahan reranting masa lalu & & di-, -ku, \\
\hline Di sini, kau akan kutunggu & & -ku \\
\hline Sampai ujung waktuku & \\
\hline
\end{tabular}

\section{KESIMPULAN}

Pertama, objek kajian terbesar dalam morfologi adalah kata dan objek kajian terkecil adalah morfem. Kedua, morf dan alomorf merupakan unsur dari morfem. Ketiga, berdasarkan kedudukannya morfem terdiri dari morfem bebas dan morfem terikat. Keempat, Semua awalan, imbuhan, dan gabungan antara awalan dan imbuhan adalah juga termasuk morfem terikat, serta kata yang membutuhkan morfem lain juga disebut morfem terikat. Kelima, dalam puisi "Embun Di Hutan Jati" karya Candra Malik lebih banyak didominasi morfem terikat yang berupa alomorf daripada morf. Yaitu; morfem dasar terikat, me- dan ber-.

\section{REFERENCE}

Azizah, S., Setyadi, A. and Astuti, S. P. (2018) 'Proses Morfologis Kata Minta Dan Sinonimnya', Semarang, pp. 1-11.

Edward, S. (1921) “'Language: An Introduction to the Study of Speech (Lengua: una introducción para estudio discursivo), $15(18)$, p. 142. doi: $10.2307 / 4388302$.

Pramudiah, P. W. et al. (2018) 'Proses Morfologis Kata Maju Beserta Turunnya', Semarang, (024), pp. $1-10$.

S, M. Z. (n.d.) kurniawan, m. s. (n.d.). text analysis of poetry in hand book teacher. authentic assessment book publisher erlangga, 1-11.

(Mael, no date) Hidayat, R. (no date) 'ANALISIS PUISI DENGAN PENDEKATAN HERMENEUTIKA', pp. 61-68. 
Mulyati, S.-. (2019). the Analysis of Five William Blake'S Poems. Wanastra: Jurnal Bahasa Dan Sastra, 11(2), 113-120. https://doi.org/10.31294/w.v11i2.5414

Prihantono, K. D., Bahasa, B., Jawa, P., Raya, J. E., \& Whitman, W. (2014). ANALISIS PENERJEMAHAN PUISI " I HEAR AMERICA SINGING " KARYA WALT WHITMAN: SEBUAH KAJIAN. 173-186.

Hidayat, R. (no date) 'ANALISIS PUISI DENGAN PENDEKATAN HERMENEUTIKA’, pp. 61-68.

'Syair al khansa sebuah analisa sastra $=$ Al khansa poetry an analytical literature' (no date), $p$. 20392695.

Letters, F. O. F. (2015) 'The Image of Women in Lady Mary Chudleigh Poems: The Ladies ' Defense and To the Ladies FACULTY OF LETTERS AND HUMANITIES'. 